\title{
O PREFEITO GRACILIANO RAMOS PELO OLHAR DA GESTÃO URBANA CONTEMPORÂNEA
}

\section{BRAZILIAN MAYOR AND WRITER GRACILIANO RAMOS THROUGH THE EYES OF THE CONTEMPORARY URBAN MANAGEMENT}

\author{
Clovis Ultramari ${ }^{\text {A, B, C, E, F }}$ \\ Mario Procopiuck A, B, C, E, F \\ Manoela Massuchetto Jazar A, B, C, E, F \\ Pontifícia Universidade Católica do Paraná, Programa de Pós-graduação em Gestão Urbana, Curitiba, PR, Brasil
}

R E S U M O : Este artigo integra uma pesquisa relativa à transferência de ideias sobre cidades em distintos níveis temporais e geográficos. Aqui, procedeu-se à crítica dos relatórios da gestão do prefeito Graciliano Ramos, em Palmeira dos Índios, Alagoas, nos anos 1920, e seu uso como referência de ideal para gestores municipais de nossa atualidade. Discute-se: 1) o conceito de transferência de ideias em recortes temporais, como nos chegam e como se atualizam aquelas entendidas como corretas em tempos pretéritos; e 2) a referência acrítica feita, pelo gestor atual, da prática utilizada por Graciliano. Apoia-se em referencial teórico, leitura crítica dos relatórios, levantamento bibliométrico e surveys. A análise é qualitativa. As conclusôes reiteram a importância do trabalho do prefeito limitada ao seu tempo histórico, porém sugerindo um estranhamento frente à sua permanência como modelo de gestão municipal e à superficialidade, intencional ou não, de como essa referência é feita contemporaneamente.

P A L A V R A S - C H A V E : Graciliano Ramos; transferência de ideias; migração de ideias; gestão urbana; cidade.

A B S T R A C T : This article is based on municipal reports signed by Mayor Graciliano Ramos of the municipality of Palmeira dos Indios, Alagoas, Brazil, and discusses his public performance through the perspective of contemporary paradigms. The discussion refers to 1) the concept of transfer of ideas along time and how they may be considered as adequate in distinct times and 2) the fact that researchers take their object of investigation in myths, somewhat justifying the recurrence of the image of Graciliano as a model for those who struggle for decency and fight corruption in public management. Sources used for developing this research were theoretical reviews, the reports themselves, a bibliometric study and surveys. Analyses are qualitative. Conclusions suggest, still preliminarily, that the importance of Graciliano's work as a mayor should be restricted to his own time; if scrutinized by urban management or public policies contemporary parameters, it deserves a higher skepticism.

K E Y W O R D S : Graciliano Ramos; transfer of ideas; cities; literature; urban management.

Contribuição de cada autor/a: A. fundamentação teórico-conceitual e problematização; B. pesquisa de dados e análise estatística; C. elaboração de figuras e tabelas; D. fotos; E. elaboração e redação do texto; F. seleção das referências bibliográficas.

DOI: https://doi.org/10.22296/2317-1529.2017v19n1p64 


\section{INTRODUÇÃO}

Este texto discute a gestão de Graciliano Ramos no final da década de 1920 - anos pré-revolucionários da política brasileira e com hegemonia do coronelismo regional - pelo olhar de uma gestão urbana contemporânea idealizada. $\mathrm{O}$ interesse do artigo é o de discutir as qualificaçôes que são dadas atualmente à prática então exercida por Graciliano Ramos na prefeitura de Palmeira dos Índios, cidade do agreste alagoano, a $134 \mathrm{~km}$ de Maceió - naquela época a quarta cidade em volume demográfico do estado, hoje a terceira. Esquivando-se, propositadamente, de avaliá-la, seja pela perspectiva de modelos atuais, seja por contextualizaçóes de seu momento histórico, debate-se a apropriação acrítica de um determinado modelo de gestão e a não avaliação de como ele poderia, de fato, ser adotado entre nós. Interessa-nos discutir aqui como ideias referentes à gestáo urbana permanecem ou são descartadas em diferentes recortes temporais. Explicitamos, pois, uma constataçấo a respeito da impermanência e ressignificação das coisas, com a revisão constante daquilo que uma vez nos pareceu como absolutamente correto nos esforços de se garantir uma vida melhor para as cidades. De fato, estudos diversos atestam uma periodização jamais finalizada sobre os modelos do "bem gerir" as cidades, uma constante substituição de cânones do ideal para a gestão urbana (SANTOS, 1994; LEME, 1999; FELDMAN, 2001; 2014; ULTRAMARI; FIRKOWSKI, 2012).

A cada nova intenção de se "bem gerir" a cidade, alternam-se ideias e práticas referenciais, complementam-nas, reafirmam-nas e, também, radicalmente as rejeitam. Vive-se sob o princípio de um modelo buscado - náo necessariamente implementado - de gestão urbana, com maior ou menor distinção do que se buscou em épocas precedentes: uma insatisfação cíclica que Milton Santos (1996) qualificaria como modismos sucessivos, ao discutir pesquisas sobre o fenômeno urbano. No momento presente da gestão urbana brasileira, tomamos como cânones da boa gestáo a valorização da participação popular, a transparência político-administrativo-financeira, a prioridade de atuação em áreas mais carentes da cidade e o respeito a compromissos ambientais. Tais cânones podem ser confirmados no espírito de muitas das legislaçóes urbanas em vigor no Brasil e que resultaram de um longo processo de debate societário. São exemplos o Capítulo da Política Urbana na Constituição Federal de 1988, o Estatuto da Cidade (Lei Federal 10.257, de 2001) e, mais recentemente, o Estatuto da Metrópole (Lei Federal 13,089, de 2015). A partir do aí observado, conscientes dos limites do idealizado, selecionam-se os atributos que qualificariam o modelo de gestáo contemporânea neste artigo, os quais, a história nos ensina, também serão um dia revistos, substituídos ou complementados.

A busca de maior compreensão sobre como ideais podem complementar-se ou distanciar-se em função de situações fático-circunstanciais passadas e presentes é o que nos instiga a escrever o presente artigo.

Entre o discurso trazido nos relatórios do prefeito Graciliano Ramos (PMPI, 1929; 1930) e aquilo que se acredita ser os cânones da gestão contemporânea ideal, já se reconhecem permanências: uma explícita prioridade pelas faixas mais carentes da população, o interesse público das coisas do Estado e a transparência de açóes governamentais. De modo geral, no período entre a gestáo de Graciliano Ramos e o da cidade contemporânea, alguns ideais parecem, estranhamente, permanecer; a prática 
para suas consecuçôes, ao contrário, indica fortes mudanças. Parece, então, haver permanência dos princípios, mesmo que com mudanças de objeto - um mundo menos ou mais urbanizado, cidades mais ou menos próximas do mundo rural - e mudanças político-administrativas de um e de outro tempo - um mundo menos ou mais regrado legal e institucionalmente.

Reconhecem-se limitações na avaliação, pelo olhar contemporâneo, de posturas de um passado e de uma realidade distantes. O exercício analítico é feito sobre a pertinência de se adotarem, sem lembranças de contexto, posturas e açóes do gestor Graciliano Ramos como referenciais para qualificar gestores urbanos de hoje. Não se discute aqui a importância daquele prefeito para a cidade de sua época; a discussão prioriza procedimentos miméticos, pouco contextualizados, observados na idealização de exemplos passados.

\section{SOBRE A TRANSFERÊNCIA DE IDEIAS}

Estudos sobre transferência de ideias parecem ser escassos no cenário brasileiro; porém, não são recentes. Schwarz (1981) preocupou-se em entender como ideias liberais advindas de países ocidentais serviram para fundamentar uma ideologia do arbítrio e da dependência no cenário brasileiro; Rouanet (1992, p. 330) retornaria a essa questão, afirmando que "um pensamento não é universal quando anula as particularidades locais, mas quando tem a força para integrá-las e quando, graças a esse pensamento, as particularidades encontram uma forma concreta e inteligível”.

Entre fluxos e sedimentaçóes de ideias, preocupa-se, no recorte temático da pesquisa, com a transferência das ideias sobre o urbano; no nível espacial, como ocorrem trocas de conhecimentos e práticas entre diferentes lugares e territórios, e, no nível temporal, como são feitos repasses e absorçôes desses mesmos conhecimentos e práticas entre momentos distintos. Neste artigo, interessa-nos debater como tais transferências configuram-se em estratégias de resistência a mudanças em termos de construção e apropriação das cidades ou de permanência de modelos de cidade por determinados grupos sociais. A esses grupos interessa, de fato, a mitificação do passado.

Esse é o contexto em que se insere o debate sobre uma determinada transferência temporal de ideias ou, melhor dito, a referência que se faz de Graciliano como modelo de gestão presente: pretenciosa, por parecer ignorar as dificuldades de se transpor distinções entre um e outro momento histórico, e rápida, por idealizar acriticamente o passado.

Quando falamos em períodos da gestão urbana brasileira, referimo-nos a eles apenas como uma ferramenta analítica, reconhecendo que são mutáveis por alterarem o objeto sintetizado - a cidade - e nossos olhares sobre ela: periodizaçóes representam uma "síntese de grandes momentos, ainda que [esses] guardem particularidades e que algumas realidades se sobreponham temporalmente" (ULTRAMARI; FIRKOWSKI, 2012, p. 2). Assim, o atual estágio da gestáo urbana contemporânea ora pode parecer mais similar, ora mais distinto daquele que contextualizou a gestão de Graciliano Ramos como prefeito; sendo, portanto, ora mais, ora menos aceitável analisá-la ou qualificá-la por parâmetros atuais. 
Ideias, ou melhor, ambientes de ideias que se distinguem social, política, técnica, econômica e culturalmente num contexto ampliado contribuem para que determinados períodos de uma história urbana constituam conjuntos difusores de princípios, conceitos, diretrizes e mesmo desejos. Na concretude dessa transformação, ou melhor dito, da transferência concreta de uma ideia (que, para a gestáo urbana, configura-se na adoção alhures de princípios, projetos, planos, corpo de legislaçôes, práticas) estão, dentre outros fatores, a comunicação "entre" e a migração "de" seus autores diversos. A despeito de se poder identificar uma longa lista, sempre incompleta, de fatores que explicariam a transferência de ideias, ou mesmo da priorização de alguns desses elementos explicativos, haverá sempre atributos que desconhecemos, complexos, pouco evidentes, resultantes de uma situação única e de um ser (elemento da comunicação para a transferência) igualmente único. Assim, vale aqui a lembrança de que somos, assim como nossas ideias o são, nós mesmos e nossas circunstâncias (ORTEGA Y GASSET, 1914). Tal observação reitera a diversidade de fatores que pode influenciar na constituição de um fato, mas, mais claramente, indica uma dificuldade em apreendê-los sintética e certeiramente para replicá-lo em contextos espacial e temporalmente distintos. As ideias explicitadas por Graciliano em seus relatórios são transferidas para o nosso tempo presente e marcadas pela distinção literária do autor, pela sua clara opçâo ideológica polarizada - coerente com seu tempo vivido, no Brasil e no mundo - e pelo seu cárcere na ditadura de Getúlio Vargas. Esses fatores parecem estabelecer-se como chancelas de suas ideias de gestão urbana para a contemporaneidade sem que se procedam avaliaçôes críticas, sem um crivo de como poderiam ser implantadas nas nossas cidades, sugerindo uma fácil reprodução do excelente escritor em excelente administrador.

No caso do estudo da transferência de ideias sobre cidades, reconhece-se, há um vício ostensivo com sua apresentação gráfica. Para Jammet (2009, p. 22), a ideia urbana seria uma representaçấo objetiva ou subjetiva que se tem para visualizar a cidade, a partir de imagens construídas por grupos de poder, transmitida por técnicos e profissionais que "posteriormente diseñarán y concretarán esta idea". Hall (2011), também valorizando a importância gráfica da ideia, entende-a como arrogância de planejadores e indício da distância entre prática de urbanismo e realidade. De modo distinto, no caso dos dois momentos discutidos neste artigo, a ideia sobre a cidade configura-se não pelo desenho, mas por meio de práticas gerenciais, institucionais e legais; diminuindo, assim, a importância do desenho como forma de expressão de um ideal.

O uso indistinto entre ideia e representação para o caso da cidade é, de fato, recorrente na literatura. Rojas Muñoz (1989), por exemplo, reconhece na representação gráfica da cidade um instrumento de expressão de um ideal e também de difusão de um propósito. Foucault (2008) avança com esse raciocínio no sentido de classificar tais ideias e representaçôes como iniciativas públicas ou privadas em benefício e interesse próprios. Estar-se-ia, pois, próximo do entendimento de dispositivos de controle e geração de conhecimento por entes sociais dominantes. Essa transferência caracteriza-se pela forma como ocorre, pelo instrumento de que se serve, pelo perfil dos interlocutores e, sobretudo, pela relação que esses estabelecem: em um extremo, dialógicas; em outro, hierárquicas.

Denominada e definida por conceitos variados, transferência ou mesmo exportação de ideias, conforme Stone (2004), é uma tradição já conhecida e utilizada em 
níveis internacionais desde os tempos coloniais. Parnreiter (2011) reforça a afirmação sobre a internacionalização da transferência, agora incentivada por governos nacionais e agências de desenvolvimento. Por último, vale citar Healey (2012), que reconhece, para a área do planejamento e gestão urbana, a existência de um intenso "fluxo transnacional de ideias", sempre sujeito a novas características e interpretações.

Para o caso específico da gestão urbana, e que se aplica no estudo dos trabalhos de Graciliano junto à prefeitura de Palmeira dos Índios, é possível afirmar que a transferência de ideias é empreendida sobretudo quando da necessidade de rápida solução para problemas locais ainda não experimentada. Ultramari e Duarte (2009), por exemplo, inserem essas situaçóes conjuntamente com a especificidade de situaçôes políticas, crises, avanços econômicos, características geográficas, imposiçôes religiosas e disponibilidade de tecnologias, lembrando o fenômeno de inflexôes urbanas, as quais exigem um novo pensar para gerir situaçóes até então desconhecidas. Confirmar a existência e entender como teria sido o diálogo de Graciliano com prefeitos da região sobre suas experiências na gerência pública comprovaria um eventual interesse em "aprender com o outro" e de assimilar o "já testado". No caminho inverso de uma possível transferência de ideias, olhar para a gestão de Graciliano a partir da cidade contemporânea sugeriria, minimamente, um interesse no enfrentamento dos problemas de utilização do recurso público.

Transferências de ideias podem ainda ser melhor contextualizadas por meio do modo como são constituídas, ou seja, de fato repassadas, observadas ou assimiladas. Em tal processo, são observadas complexidades sobretudo naquilo que diz respeito à miríade de atores e locais com níveis diversos de poder e habilidades, diferenciando aqueles com maior capacidade para desempenhar o papel de repasse e mesmo de imposição de ideias daqueles com decisão ou interesse no exercício da adaptabilidade ou simples replicabilidade. Tais hierarquias são instáveis e alteram-se em distintos modos e razôes de difícil apreensão (MÜLLER, 2015). No caso da gestão de Graciliano Ramos, não há sequer uma representação gráfica ou um conjunto de ideias constituídos como tal e por ele elaborados. Há uma prática demonstrada e que, portanto, deixa ao observador uma maior liberdade analítica para formatar e, assim, justificar sua aprovação, rejeição ou mesmo mitificação.

A despeito de a transferência de ideias poder incluir um amplo espectro de "capital" que pode ser repassado ou assimilado, para Howlett e Morgan (2010), no nível da gestáo urbana, ela é caracterizada pela concreta mobilidade do conhecimento e por práticas com potencial transformador - social e físico - no espaço das cidades. De acordo com tais autores, partes ou totalidades de ideias sobre cidades podem migrar 1. com a conservaçáo da integridade original ou 2. com a conservaçáo da ideia em termos de utilidade e funcionalidade, porém submetida a novas funçôes (travelling fruitfully). A despeito dessas comunicaçóes serem inicialmente tomadas como açóes colaborativas, Healey e Upton (2010) reiteram a sua necessária validação social e o sempre presente interesse: transferir ideias pode, pois, ocorrer de modo mais receptivo ou de modo mais impositivo. A perspectiva trazida por esses autores ajuda-nos a indagar sobre a real possibilidade de uma migração de ideias da gestão de Graciliano para a atualidade de modo integral, sem distinção entre aquilo que lhe fora princípio (atributo duradouro) daquilo que lhe fora prática (modo operacional mais sujeito a especificidades de tempo e lugar).

Leme (2004), ao apresentar seu trabalho sobre a formação do urbanismo em 
São Paulo, rejeita a palavra "influência” por não dar conta da complexidade existente nesse processo e mesmo "transferência", por simplesmente reiterar um contexto de apropriação de ideias. Opta, assim, pela expressão "circulação" de ideias. Também nesse trabalho, Leme (2004) identifica três hipóteses a respeito da referida circulação de ideias sobre cidades: o urbanismo é um movimento de âmbito internacional que se destaca pelo trânsito de ideias-chave; é um campo de trocas de experiências; e, por ser um campo com crescente autonomia, reflete na organização das instituiçôes de ensino e associações profissionais. A popularização mais recente da gestão de Graciliano, mantida pela influência do seu nome como escritor de referência nacional, pode também ser explicada por uma ideia-chave que seria a da lisura no trato do interesse público e da facilidade com que tais ideias podem atualmente circular e ser analisadas e apropriadas. Todavia, a facilidade ofertada pelos meios de comunicação hoje disponíveis, paradoxalmente, pode também reiterar aquilo que nos é mais facilmente assimilado e que já nos é familiar. Estudo de Tomlinson et al. (2010) sobre as boas práticas em cidades de países em desenvolvimento no ambiente Google, por exemplo, revela que esse instrumento contribui para uma maior generalização de perspectivas hegemônicas. Ironicamente, o ambiente mais completo para a circulaçáo de ideias seria então organizado para limitar o acesso a "alternative policy perspectives and debate, and that is not in the public interest" (TOMLINSON et al., 2010, n.p.).

A discussão teórica sobre o contexto maior da pesquisa - transferência de ideias sobre cidades e sua gestão - aqui apresentada não intenciona, nem poderia, esgotarse neste artigo. Foram trazidas para o presente debate aquilo que mais diretamente pode contribuir para entender o fenômeno de uma migração transtemporal de uma ideia e de chancelá-la como válida em seus princípios e em sua prática. Na sequência, apresentamos um breve contexto político da eleição e gestâo de Graciliano e a escrita de seus relatórios.

\section{POSSE, RELATÓRIOS, RENÚNCIA}

Nas quatro décadas em que vigorou a primeira constituição republicana brasileira, de 1891, "preponderou o coronelismo e o centralismo regional, que transformaram os municípios em feudos políticos marcados pelo mando e o desmando, como fossem propriedades particulares" (MEIRELES, 1996, p. 36) e, "nessa atmosfera de opressão, as instituiçóes locais não puderam encontrar campo para seu desenvolvimento" (MONTORO, 1975, p. 41). É esse mesmo cenário que justifica, por mais de uma vez, a observação de Graciliano sobre o contexto de sua própria eleição, revelando ou conivência ou estratégia tácita frente a um modo eleitoral há muito criticado: "Assassinaram meu antecessor. Escolheram-me por acaso. Fui eleito naquele velho sistema de atas falsas, os defuntos votando" (RAMOS, 1948 apud MORAES, 2012, p. 61). O governo de Graciliano fora antecedido por Lauro de Almeida Lima, assassinado por um fiscal de impostos de Alagoas, antes de finalizar seu mandato, o qual seria assumido por Manoel Sampaio Luz até as novas eleiçóes.

A eleição de Graciliano Ramos para prefeito, antecedeu a uma tragédia política que ocorreu em Palmeira dos Índios; uma destas lutas tão comuns que ainda hoje acontecem no nordeste brasileiro; lutas cevadas pelas intrigas, calúnias, difamaçóes, fuxicos do "disse me 
disse", do "me contaram", que ocorrem de boca em boca nas rodas dos politiqueiros ou desocupados nas mesas dos botequins. Ele seria o homem indicado por náo ser um tipo que se envolvesse em baixezas (SILVEIRA, 1982, n.p.).

O momento vivido no Brasil à época da gestão de Graciliano é também aquele frequentemente denominado de pré-revolucionário, com a desintegração da Primeira República, insurreições, crise econômica e também uma insatisfação intelectual que seria destacada pelo Movimento Modernista (LUZ, 1969). Sant'Ana (2003), por exemplo, destacaria a década de 1920 em Alagoas como de efervescência cultural e que permitiria uma singular produção regional, refletindo aquilo que ocorria nos maiores centros do Brasil de então. Entretanto, característica que sempre se destaca nas análises dessa década é a de uma "insatisfação dos setores médios da população urbana, descontentes com as instituições de uma república dominada pela oligarquia rural" (SANT'ANA, 2003, p. 68). Graciliano, na chefia do poder executivo municipal, teria vivenciado e reconhecido essa dupla insatisfação: um desejo de modernidade que convivia com um tradicionalismo, patrimonialismo, coronelismo, mandonismo e clientelismo, conforme lembrado por Carvalho (1997).

Durante a Primeira República (1989-1930), a qual Graciliano vivenciara os últimos tempos, as limitaçóes impostas à autonomia municipal reforçavam a consolidação do poder central por meio dos governos estaduais. Disso resultaria a "política dos governadores", sistema de relaçóes entre estados e municípios fundamentado em compromissos eleitoreiros e de práticas coronelistas. No nível local, tais acordos garantiam que lideranças, como contrapartida, recebessem condiçóes necessárias para a montagem de oligarquias municipais (LEAL, 1997).

Ainda que a renúncia de Graciliano tenha sido influenciada por questóes pessoais, a posterior saída do seu governador e coligado do poder confirma a gestação de uma crise: em 1930 seria derrubado pela chamada Revolução que iniciaria a Era Vargas. O prefeito que lhe sucedeu foi José Helenildo Ribeiro Monteiro, inaugurando uma fase de conivência com o governo getulista.

No cenário nacional, acumulavam-se problemas estruturais agravados pela crise financeira internacional de 1929; no nível local, incrementavam-se as dificuldades de governabilidade, fato que também pode ter acelerado a renúncia de Graciliano. Documentos pessoais, como cartas à esposa, Heloísa, revelam, entretanto, um decidido desejo de renunciar ao cargo e sair de Palmeira dos Índios: "Consideras-te rival da prefeitura, minha filha? Que lembrança! Há apenas entre mim e ela uma ligação precária, por três anos, mas se achas a ligação indecente, desmancho tudo e mando-a pentear macacos" (RAMOS, carta de 8 de fevereiro de 1928, p. 104).

Do mesmo modo, conforme afirma Moraes (2012, p. 50), Graciliano não esconderia seu tédio pela pequena e isolada Palmeira dos Índios de então:

Melancólico, dizia que sua atividade em Palmeira se concentrava "em coisas que andavam muito distantes do cérebro”. Um dado interessante é que ele afiançava a Pinto que se não fosse pelos filhos pequenos, teria voltado para o Rio: "Malgrado as desilusóes, a cidade ainda me tenta. Se um dia me for possível, voltarei. É um sonho absurdo, talvez”. 
Por último, não se pode desconsiderar o ambiente de oposição política existente para a decisão de renúncia, tomada em 30 de abril de 1930: "Houve quem tivesse comemorado a sua saída. Eram pessoas que tiveram interesses contrariados, porque ele não fazia cambalachos, nem dispensava multa de ninguém” (MORAES, 2012, p. 72).

À época, relatórios como os de Graciliano eram eventualmente publicados em diários oficiais e jornais locais, normalmente a título de mensagens aos Conselhos Municipais (Câmaras de Vereadores). Dele, conta-se com dois desses relatórios, ambos com explicitação detalhada de receitas e despesas, aqui discutidas pelo olhar (arriscado) do modelo de gestáo urbana idealizado contemporaneamente. Conforme já anunciado, seu reconhecimento como escritor contribuiu para que esse material de caráter administrativo tenha sido preservado e tomado como referência em estudos diversos. $\mathrm{Na}$ inexistência de tal circunstância, dificilmente tais documentos teriam recebido igual atenção; esta é a conclusão que se tem ao buscarmos relatórios de seus pares contemporâneos, anteriormente à elaboração deste artigo (salvo, eventualmente, com a realizaçáo de pesquisas primárias mais específicas).

A qualidade literária de Graciliano Ramos é mais comumente observada a partir de sua obra Caetés, publicada em 1933. Cândido (1992, p. 23), por exemplo, afirma que a partir desse momento o autor ganhou maturidade genial e "se libertou para as obras-primas". Do mesmo modo, Mello (2012, p. 44) resume seu estudo sobre a crítica recebida pelas obras de Graciliano Ramos da seguinte forma: "As mençóes positivas por parte da crítica à obra de Graciliano, como as citadas acima, poderiam ser reunidas às centenas desde a sua estreia com o romance Caetés até os dias de hoje".

A produção de Caetés teria ocorrido entre 1925 e 1928, ou seja, teve sua finalização acumulada com o exercício de prefeito. Há, então, uma concomitância temporal entre a produção do livro que distinguiria sua prática literária e a prestação de contas ao seu governador. Mais intrigante seria o impacto imediato causado por tal prestação:

Graciliano, por volta de seus 36 anos, vivia uma vida modesta e condenada à rotina morna de uma cidade do interior do estado de Alagoas. Em 1929, o autor do romance foi descoberto por Augusto Schmidt, editor de livros da cidade do Rio de Janeiro, não exatamente em virtude desse primeiro romance [Caetés], mas por meio dos relatórios escritos por GR como prefeito da cidade de Palmeira dos Índios (AYUB, 2016, p. 51).

Confirma-se então a importância dos relatórios no prosseguimento da vida literária de Graciliano: pelo natural exercício da palavra, mas também por fato circunstancial de evocar o interesse do escritor José Américo de Almeida e, por intermédio desse, do poeta e editor Augusto Frederico Schmidt, o qual teria requisitado a Graciliano "tirar o romance que tinha na gaveta [Caetés] e publicá-lo". O impacto dos relatórios de Graciliano foi significativo: José Lins do Rego (circa 1934), antes relutante em valorizar sua escrita, mais tarde o faria irrevogavelmente. "Mesmo o seu relatório, cheio de boas pilherias que êle viria a enviar ao governador náo achei essa cousa admirável que Schmidt descobrira. Aquilo ainda me parecia excentricidades [...]".

Jaconi (2012, p. 18), por exemplo, fala em "liberdade transgressora" ao se referir ao estilo adotado nos referidos relatórios, os quais "causaram estranhamento da mídia na época, devido à contravenção da linguagem oficial do gênero relatório”. Prosseguindo, a autora reitera: "Assim foi Graciliano Ramos quando escreveu os relatórios 
públicos sobre sua administração pública na cidade de Palmeira dos Índios - um especialista transgressor do gênero relatório que, através de sua intimidade com a linguagem artística, conferiu sabor e encanto aos textos destes documentos" (JACONI, 2012, p. 20).

Tem-se entâo uma eventual inversão de valores em casos relatoriais: a forma da descrição toma mais importância que o próprio objeto relatado, a cidade de Palmeira dos Índios.

Em 1920, Palmeira dos Índios, Alagoas, contava com 39.241 habitantes (BRASIL, 1926, p. 333); em 1930 não se realizou censo; em 2010, seriam 70.368 habitantes (IBGE). À época de Graciliano, a prefeitura contava com onze funcionários, hoje conta com aproximadamente 2.000 (PMPI, 2014). De imediato, se tomada em conta a população municipal dividida pelo número de funcionários da prefeitura, houve acréscimo da relação de 3.567 habitantes por funcionário na década de 1920 para trinta e cinco em 2010.

Em termos de estrutura urbana, a Palmeira dos Índios vivida e gerida por Graciliano reproduz a vida de uma cidade pequena do interior, em um país com processo de urbanização incipiente em escala urbana de consolidação de seus espaços e aparato administrativo. Algo mudaria em 1933 com a chegada da ferrovia, já distante dos anos de Graciliano na prefeitura: é nesse momento que a cidade assume maior destaque econômico e influência regional, permitindo a "notável expansão do comércio e dos serviços" (CORRÊA, 1997, p. 97). A cidade real, objeto dos relatórios de Graciliano, parece entấo reiterar aquela apreendida na obra Caetés que nos sugere um "cotidiano tacanho e dos tipos miúdos que se condicionam à sensaboria da província [...] com seus costumes e sua pasmaceira" (GIMENEZ, 2008, p. 166). Todavia, é da própria escrita de Graciliano em Caetés que temos, talvez, a descrição mais abrangente de um vilarejo lento, ironicamente indeciso entre o urbano e o rural: "Olhei a rua. À entrada do Pernambuco-Novo um automóvel parado atravancava a passagem. Uma carroça de lixo, vagarosa, rodava” (RAMOS, G., 2013, p. 96).

\section{METODOLOGIA E INFORMAÇÕES}

Quando da proposição inicial deste artigo, três caminhos metodológicos pareciam possíveis para debater transferência de ideias. O primeiro, sugerido pela recorrência da imagem de Graciliano como modelo de gestor, dizia respeito à transferência de ideias em nível transtemporal, entre sua atuação na prefeitura e a gestão das cidades contemporâneas. $\mathrm{O}$ segundo, unitemporal, debateria a relação entre obra literária de Graciliano e sua atuação política como prefeito, aproximando dois campos investigativos, o da literatura e o da gestáo das cidades. O terceiro, também unitemporal, seria a pesquisa sobre a relação entre a gestão de Graciliano e a de seus pares gestores da época. Tentativas foram feitas para os municípios alagoanos vizinhos de Palmeira dos Índios: Santana do Ipanema, União, Viçosa e Anadia, todos com aproximadamente 50 mil habitantes (IBGE, 2010). Tal intenção não se efetivou em razão da não disponibilização de relatórios equivalentes aos produzidos por Graciliano ou mesmo da incerteza da sua elaboração. Tais materiais seriam fundamentais para uma análise comparativa capaz de esclarecer os atributos político-administrativos de Graciliano 
pela perspectiva de seu próprio tempo. A terceira opção metodológica exigiria ainda avanços analíticos no campo da literatura; todavia, parece contar com afluência de informaçóes. Nesse caso, estaria destacada a perspectiva pessoal de Graciliano com o cotidiano de uma cidade do interior esquecido de Alagoas: "Consideras-te rival da prefeitura, minha filha? Que lembrança! Há apenas entre mim e ela uma ligação precária, por três anos, mas se achas a ligaçáo indecente, desmancho tudo e mando-a pentear macacos" (RAMOS, carta de 8 de fevereiro de 1928, p. 104).

Escolheu-se o primeiro caminho. O segundo careceria de informações não obtidas até então.

A valorização da leitura da obra de Graciliano como fonte de investigação sobre um tempo e um contexto, ou, no caso, um modo de habitar um espaço e geri-lo, parece ser por ele mesmo anunciado: "Nunca pude sair de mim mesmo. Só posso escrever o que sou. E se as personagens se comportam de modos diferentes, é porque não sou um só" (RAMOS apud MORAES, 2012, p.15). A mesma defesa é feita por Cândido (1992), ao ampliar o valor de uma obra para o contexto em que foi escrita, o cenário real que apresenta e a ideologia do autor em relação a esse mundo. De modo similar, essas seriam questóes basilares para o estudo da cidade, sempre defendidas como necessárias para sua compreensão e intrinsicamente presentes num campo interdisciplinar de estudo.

Apesar da crítica mais em voga (reagindo contra certos exageros de origem romântica) a obra vale por si, e em si mesma deve ser considerada, independente da pessoa do escritor, náo nos furtamos à curiosidade que este desperta. Se cada livro pode dar lugar a um interesse apenas imediato, isto é, esgotado pelo que ele pode oferecer, uma obra, em conjunto, nos leva quase sempre a averiguar a realidade que nela se exprime e as características do homem a quem devemos esse sistema de emoções e fatos tecidos pela imaginação (CÂNDIDO, 1992, p. 69).

Quando da escolha do primeiro caminho metodológico citado acima e da leitura preliminar dos dois relatórios apresentados ao governador de Alagoas por Graciliano Ramos, já se concluía a possibilidade de neles haver um grande potencial analítico, porém pouco confrontados com as atuais diretrizes de uma política urbana nacional. Ao fazer parte de um grupo de intelectuais com cargos políticos, eletivos ou não, que caracterizou os anos 1930 e 1940 no Brasil, Graciliano, sobretudo em seus dois relatórios anuais ao governador de seu estado, ajudou a sintetizar o que seria o ideal urbano para a cidade da época, ou seja, a melhor definir o que teria sido o período da gestão urbana por ele vivido. Similarmente, documentos legais como a Lei de Responsabilidade Fiscal/2010, o Estatuto da Cidade/2001, e a própria Constituição Federal de 1988, por exemplo, sintetizam o regramento para o que seria uma boa gestâo da cidade brasileira; evidentemente, devido à complexidade contemporânea de nossas cidades, em menor grau de apreensão da realidade.

Antes da leitura crítica dos dois relatórios de Graciliano, realizou-se levantamento de caráter mais geral na internet (Google e Google Acadêmico, 2015) no intuito de apreender sua imagem como referência para a administração pública contemporânea no Brasil. Essa investigação é acompanhada da busca em documentos disponibilizados online em todos os Tribunais de Contas Estaduais do país, assim como no Tribunal de Contas da União (TCU), para avaliar o nível de aplicação de tais ideias 
em atividades contemporâneas de cunho regulatório. No primeiro caso, o objetivo foi o de apreender a relação de Graciliano com a probidade administrativa e com a gestáo urbana de modo mais geral. Chama a atençáo os resultados advindos do uso da palavra-chave "probidade + Graciliano Ramos", com 303 mil resultados. No Google Acadêmico, de modo esperado, o quociente cai significativamente. Devido ao grande número de retorno em ambas as fontes, procedeu-se apenas à leitura dos documentos trazidos nas dez primeiras páginas de cada um dos resultados obtidos. Esse material foi analisado e contribuiu para a discussão teórica do presente artigo. O Quadro 1 apresenta o quantitativo desses resultados.

Quadro 1: Graciliano e modelo de gestáo a partir de resultados no Google e Google Acadêmico, 2015

\begin{tabular}{|l|l|l|}
\hline Palavras chave: “Graciliano Ramos" + & Google & Google Acadêmico \\
\hline “Tribunal de Contas" & 142.000 & 471 \\
\hline “Gestáo Administrativa" & 154.000 & 705 \\
\hline "Transparência” & 229.000 & - \\
\hline "Probidade” & 303.000 & - \\
\hline "Auditoria” & 88.200 & - \\
\hline
\end{tabular}

Fonte: Organizado pelos autores.

No caso do levantamento junto aos sites dos Tribunais de Contas dos Estados e no do TCU, instituiçôes previamente consideradas como "reconhecedoras" do ideal do autor/administrador em questão, foi utilizado apenas o termo "Graciliano Ramos". Tais resultados, apresentados no Quadro 2, limitam-se a materiais disponibilizados ao acesso público, deixando presumir que há ainda um volume maior de documentos com menção ao autor; fato comprovado quando da pesquisa no ambiente Google (vide resultado de "Graciliano Ramos" + "Tribunal de Contas"). 
Quadro 2: Pesquisa documental nos sites de Tribunais de Contas estaduais e da União, 2015

\begin{tabular}{|c|c|c|c|}
\hline Regiáo & Tribunal de Contas & No de citaçóes & Categorias das citaçóes/ No de citaçóes \\
\hline Norte & Todos os Estados & - & - \\
\hline \multirow{9}{*}{ Nordeste } & \multirow{2}{*}{ Alagoas } & \multirow{2}{*}{3} & Notícias / 1 \\
\hline & & & Últimas Notícias (2) \\
\hline & \multirow{2}{*}{ Bahia } & \multirow{2}{*}{3} & Diário Oficial Eletrônico / 2 \\
\hline & & & Notícias / 1 \\
\hline & \multirow{3}{*}{ Paraíba } & \multirow{3}{*}{3} & Notícia Externa / 1 \\
\hline & & & Informativo / 1 \\
\hline & & & Ata de sessão / 1 \\
\hline & Sergipe & 1 & Artigo / 1 \\
\hline & Demais Estados & - & - \\
\hline \multirow[b]{2}{*}{ Centro-Oeste } & Distrito Federal & 1 & Conteúdo Web / 1 \\
\hline & $\begin{array}{l}\text { Goiás, Mato Grosso, } \\
\text { Mato Grosso do Sul } \\
\end{array}$ & - & \\
\hline Sudeste & Todos os Estados & - & - \\
\hline \multirow{6}{*}{ Sul } & \multirow{4}{*}{ Paraná } & \multirow{4}{*}{36} & Documentos / 4 \\
\hline & & & Pautas / 4 \\
\hline & & & Diários Eletrônicos/Atos Oficiais / 25 \\
\hline & & & Leis Orçamentárias / 3 \\
\hline & Santa Catarina & - & 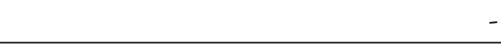 \\
\hline & Rio Grande do Sul & 2 & Biblioteca Eletrônica / 2 \\
\hline \multirow{3}{*}{\multicolumn{2}{|c|}{ Tribunal de Contas da União }} & \multirow{3}{*}{24} & Acórdãos / 7 \\
\hline & & & Ata de sessão / 12 \\
\hline & & & Biblioteca Digital / 5 \\
\hline & Total & 73 & \\
\hline
\end{tabular}

Fonte: Organizado pelos autores.

Obs.: No caso de Alagoas, contribui para as várias mençóes o Portal de Transparência do Estado, o auditório do Tribunal de Contas e a Imprensa Oficial que levam o nome de Graciliano Ramos. No caso do Rio Grande do Sul, a biblioteca digital leva seu nome; já no caso do Paraná, as mençôes se referem à Escola Estadual Graciliano Ramos.

Dos resultados do quadro 2, o que mais impressiona são as recorrentes mençóes elogiosas à figura de Graciliano em acórdáos e atas do TCU, confirmando a ampliação da imagem de Graciliano para além dos limites de sua cidade e de seu estado. Deste volume, selecionamos excertos de quatro documentos:

$\mathrm{Na}$ condição de prefeito da cidade alagoana de Palmeira dos Índios (AL), Graciliano

Ramos é o autor da mais importante peça histórico-administrativa brasileira. Trata-se do relatório de sua gestão. [...]. Insisto no registro pois o relatório aborda questôes da administração municipal que tantas vezes frequentam a pauta das Sessōes desta Câmara (TCU, 2003, p. 2).

O TCU é casa de grandes exemplos e virtudes. [...] esta Casa é também de grandes alagoanos. [...] Se pudesse, chamaria aqui o testemunho do escritor Graciliano Ramos. Não só pela pujante obra literária, plena de significação política, mas pelo exemplo de administração proba à frente da prefeitura de Palmeira dos Índios, (TCU, 2006, p. 25). 
[...] Alagoas, terra do sempre lembrado e digno Graciliano Ramos, cujos dois famosos relatórios na prefeitura de Palmeira dos Índios deveriam servir de norte aos homens públicos do país (TCU, 2012).

[...] Graciliano Ramos: Homenagem ao Centenário de Nascimento; [...] Graciliano Ramos: O Exemplo Alagoano de Dignidade Humana [...] (TCU, 2008, p. 310).

Os resultados acima impressionam pelo volume de mençóes obtidas, pela associação da figura do prefeito Graciliano com o debate sobre a probidade administrativa na gestão pública contemporânea e pela observação dessas referências também no âmbito dos Tribunais de Contas brasileiros. Chama ainda a atenção a espontaneidade como são transferidos os discursos e as ações de uma época (final dos anos 20) para outra (a atual) e como, em nenhum momento, são feitas ressalvas críticas a uma qualidade de gestão ainda pouco escrutinizada entre nós. A leitura mais propositadamente duvidosa dos relatórios de Graciliano Ramos, como apresentada a seguir, permite, entretanto, que se lance sobre essas fácil transposição temporal de ideias e replicabilidade de qualidade do escritor para o gestor. $\mathrm{O}$ item a seguir discute tais resultados e suas eventuais carências de apreciação científica da leitura propositadamente duvidosa dos relatórios de Graciliano como referência de prática na gestão urbana contemporânea.

\section{O FLUXO DAS IDEIAS DE GRACILIANO RAMOS NO TEMPO}

Dos textos acima mencionados, sobressaem-se referências diretas dos relatórios de Graciliano em peças retóricas que avalizam conclusôes sobre o que seria uma boa gestão pública em termos de equilíbrio entre receitas e despesas, cuidados com serviços públicos básicos, eliminação de desperdícios, transparência e impessoalidade na condução dos interesses públicos.

Sua gestão ficou marcada não exatamente por atos administrativos ou decisōes políticas, mas pelo relatório que o prefeito deixou, terminado o mandato. A redação desse relatório é primorosa, pela concisão, objetividade e clareza (hoje diríamos: transparência), qualidades que vêm coerentemente combinadas com a honestidade absoluta dos dados e da auto-avaliação - rigorosíssima, sem qualquer complacência - que faz o prefeito (VIEGAS, 2010, n.p.).

Os relatórios são também reproduzidos como passagens anedóticas ou frases de efeito que enfatizariam conceitos atuais de moralidade, legalidade, profissionalismo, planejamento etc., e para contrapor práticas patrimonialistas, paternalistas, fisiologistas e clientelistas.

Graciliano Ramos é considerado o Pai da Gestão Fiscal Responsável. Ao redigir os famosos relatórios da administração [...] dava exemplo de austeridade, respeito e ética no trato com o dinheiro do povo. [...] Quando Graciliano foi prefeito, Palmeira dos Índios era uma cidade suja, com porcos andando pelas ruas. Ele ordenou que fossem eliminados. $\mathrm{O}$ encarregado de matar os porcos vadios voltou um dia, com a espingarda na mão, com a cara de assustado. O prefeito perguntou-lhe, então, se não havia mais porcos pelas ruas. 
O homem respondeu que sim, mas eram do coronel Sebastião, pai do senhor prefeito, ele não ia matar. Graciliano repreendeu-o: "Prefeito não tem pai”. Demitiu o empregado por não cumprir as ordens recebidas (TAVARES, 2014, n.p.).

A LRF regulamenta aquilo que, em tese, deveria estar na essência da administração do que é público, como nos ensinou Graciliano [...] exemplo do bom uso do dinheiro público em meio a situaçóes de adversidades, tais como pobreza, secas, clientelismo e apadrinhamento (SANTOS, 2009, p. 17).

Nos documentos selecionados para esta análise, não se encontrou qualquer evidência para que mais objetivamente pudéssemos corroborar ou refutar os argumentos de Graciliano. No uso da sua administração como referência para a gestão urbana contemporânea, a única fonte são os relatórios, com juízos do próprio prefeito. À luz dessa fonte única de referência, é compreensível concluir-se pela figura do "bom administrador" e de "bom prefeito", austero na aplicação de recursos públicos. Para uma análise de sua gestão, faltam aí, minimamente, a perspectiva de seus eleitores e o quanto nesses documentos há da intenção de o administrador ter seus atos aprovados pelo governador. Para uma transferência de suas ideias para a gestão contemporânea, há questóes que mereceriam mais atenção: a relação entre seu higienismo (comum à época) e um código de proteção dos animais da atualidade que refutaria seu extermínio de cães e porcos que perambulavam pela cidade, e a preocupação com a promoção de seus feitos pessoais, a qual seria regimentalmente coibida na atualidade.

A inesperada inserção no meio político por parte de Graciliano talvez explique outro perfil rejeitado pela gestão contemporânea: o do administrador que demonstra pouco conhecimento da realidade na qual governa. Análises de Graciliano sobre sua própria região, onde nasceu e só sairia depois da experiência como prefeito, nos parecem pouco acuradas, salvo, sempre, à existência de outras conotaçóes ou contextos. Segundo Moraes (2012, p. 122), Graciliano entenderia como "passatempos acessíveis a quase todos os roceiros" a leitura de jornais e almanaque, a discussão de política e a dedicaçáo a decorar sonetos; recursos que nos parecem, de fato, pouco acessíveis na sua época e no ambiente de sua regiáo.

Em todos os textos que referenciam elogiosamente Graciliano, há uma aparente intenção em não o contextualizar, apresentando-o em tons quase "messiânicos", como homem público com sensibilidade e capacidade muito além dos demais de sua época. Para tanto, fazem-nos falta estudos comparativos, minimamente, sobre a administração de seus pares prefeitos do final dos anos 1920 no mesmo contexto social. Do contrário, a insistência na manutenção de opiniôes idealizadas sobre o escritor-prefeito, como a do "sempre lembrado e digno Graciliano Ramos, cujos dois famosos relatórios na prefeitura de Palmeira dos Índios deveriam servir de norte aos homens públicos do país" (TCU, 2012, n.p.), pode não passar de mera apologia pautada em meritórias capacidades literárias. $\mathrm{Na}$ falta de maiores análises, corre-se o risco de perder a credibilidade de um exemplo que merecidamente deva ser copiado. $\mathrm{O}$ volume de material aqui trabalhado não permite afirmar como seriam as análises da gestão de Graciliano por seus contemporâneos; nem tampouco debater com que força persistiriam os elogios no caso de sua permanência mais prolongada no poder. Artigo no Jornal O Estado, de Recife, de 1934, parece anunciar uma permanência da 
análise positiva de seu tempo no poder municipal; entretanto, a referência, mais uma vez, é unicamente os relatórios.

Assim por 1929, mais ou menos, não houve em Alagoas quem não conhecesse Graciliano Ramos. Pessoalmente não. Que ele vivia metido em chucurus de Palmeira dos Índios. Por causa de um relatório. Um relatório táo sincero e de uma sinceridade táo forte que, se os governantes brasileiros o utilizassem sempre, haveria muito maior possibilidade de salvar o Brasil que servindo-se do finado "espírito revolucionário”. (DIEGUES JUNIOR, 1934, p. 93).

Ao visitante contemporâneo em Palmeira dos Índios pouco restou para se observar do período de Graciliano no poder. Seus relatórios já evidenciavam uma gestão obrigada a um caráter mais estritamente administrativo, de organização da estrutura municipal e menos caracterizada por práticas e obras que lhe pudessem garantir visibilidade futura.

Havia em Palmeira dos Índios muitos prefeitos: os cobradores de impostos, o comandante de destacamento, os soldados, outros que desejassem administrar. Cada pedaço do município tinha a sua administração particular, com prefeitos coronéis e prefeitos inspetores de quarteiróes. Os fiscais, esses resolviam questóes de polícia e advogavam (PMPI, 1929, p. 25).

Se por um lado tais apologias possam justificar-se em meio a um cenário de reduzidas referências de boa administração pública, elas fragilizam-se, ao mesmo tempo, por serem pouco robustas em suas referências analíticas e, também, por não serem construídas com a necessária mirada de nossa contemporaneidade. Para esse caso, vale lembrar, a gestão urbana transformou-se em algo verdadeiramente complexo, jamais constituindo o desejo, intenção ou ação isolada de um indivíduo, ainda que democraticamente eleito. $\mathrm{Na}$ complexidade de nossas cidades e de suas gestôes, crescentemente reguladas e estandardizadas, haveria pouco espaço, infelizmente, para relatórios de prestação de contas em estilo casual do narrador, prazeroso a qualquer leitor, porém pouco crível a um atualizado escrutínio político-administrativo.

A reduzida fonte de informaçóes trabalhadas para se construir a referência de Graciliano para a gestâo contemporânea exige, minimamente, que se distingam os princípios das práticas administrativas. A validade dos princípios persiste, tal qual apresentados, por exemplo, por E. Ramos (2013), e sempre observados na idealização da gestấo contemporânea. As práticas, por sua vez, merecem, pelo menos, ser discutidas sob a ótica de perspectivas diversas, evitando-se a fácil transferência de qualidades literárias para o de um bom modo de gestão: "Graciliano [...] [produziu relatórios] que primavam pelo apego ao caminho da ética e da gestâo fiscal responsável [...]” (MAIA, 2003, p. 25).

A importância referencial que os relatórios receberiam nos dias de hoje já havia sido anunciada à época. O governador Álvaro Corrêa Paes, seu coligado político, em mensagem ao Congresso legislativo de Alagoas, afirma: "A administração de Palmeira dos Índios continua a oferecer um exemplo de trabalho e honestidade, que coloca o município numa situação de destaque (PAES, 1929, n.p.). Jornal local reitera a seriedade do prefeito e chama a atenção de sua coragem para enfrentar os "prejudicados". 
O Sr. Graciliano Ramos, prefeito de Palmeira dos Índios, remeteu ao Sr. Governador do Estado um interessante relatório que merece ser lido [...]. Vê-se que o povo de Palmeira dos Índios é o mais lamurioso. Mas o Sr. Graciliano é curado de cobra e não tem medo de caretas. (Jornal O Semeador, 4 de fevereiro de 1929, p. 85).

O mesmo jornal, três meses depois, continua a elogiar o prefeito Graciliano, todavia, já respondendo a possíveis críticas: "Olhe S. Excia. que o seu relatório fez surgir muito comentário azedo. Avalie só que certo amigo nosso disse coisas brabas, coisas cabeludas a seu respeito, chamando o Sr. Graciliano até de 'futurista' [...] que injúria, Santo Deus!” (Jornal O Semeador, 4 de fevereiro de 1929, p. 87). Outro jornal local novamente valoriza a obra de Graciliano, agora, porém, inserindo-o numa lista maior de prefeitos que teriam contribuído positivamente para a transformação da vida no sertão nordestino:

São vários os municípios sertanejos alagoanos cujos dirigentes estão sinceramente empenhados em fazê-los prosperar. É este um fato auspicioso [...]. Nesse número vale salientar os Srs. Antônio Alencar e Graciliano Ramos, prefeitos respectivamente, de Mata Grande e Palmeira dos Índios. (Correio da Pedra, 15 de setembro de 1929, p. 88).

Com a necessária atualização dos parâmetros que se acreditam necessários para eventualmente termos Graciliano como um modelo para nossa gestáo urbana contemporânea, veem-se permanecer os princípios, porém discute-se a possível permanência das práticas. Uma vocação para uma administração transparente, engajada, honesta e bem-intencionada logo mostra poucas chances de sobrevivência nos tempos atuais devido, entre outros, a "descuidos" processuais administrativos, um forte personalismo, imediatismo de açóes tomadas "ao sair pela rua" ou mesmo pragmatismos muito próximos de algo que se poderia chamar de um "bom coronelismo".

No orçamento do ano passado houve supressão de várias taxas que existiam em 1928.

[...] Fiz apenas isto: extingui favores largamente concedidos a pessoas que não precisavam deles e pus termo às extorsóes que afligiam os matutos de pequeno valor, ordinariamente raspados, escorchados, esbrugados pelos exatores" (PMPI, 1929, p. 37).

Na redação dos relatórios, Graciliano certamente inovou quanto à técnica discursiva, carregada de sarcasmo.

Contrariando o que se esperava de tais escritos burocráticos, marcados usualmente pela impessoalidade, pela redundância e pelo rigor formal [...] Graciliano Ramos vale-se do uso da primeira pessoa e de uma linguagem mais prosaica [...] A realizar tal transgressáo, o narrador procurava construir para si uma imagem pautada pela correção, pela austeridade e, principalmente, pela sinceridade, adotando muitas vezes um tom confessional (SALLA, 2010, p. 123).

Essa mesma característica, porém, dificilmente poderia ser aceita na atualidade, consequência de uma tecnificação crescente em nossas administraçóes e em nossos corpos legais. Há aqui, talvez, um saudosismo de quando as coisas da cidade podiam ainda ser geridas de forma casual, ora com ganhos, ora com perdas para a coisa 
pública. Seja pela imposição de uma realidade urbana e social que se tornou mais complexa, seja em nome da validade de um processo administrativo de prestação de contas com regras mínimas, o cenário de Graciliano é distinto do atual e, por isso, seria impróprio tomá-lo como parâmetro inquestionável. Como um tópico para pesquisas futuras, seria importante buscar entender o quanto dessa reprodução que, num primeiro momento, pode parecer espontânea ou mesmo inocente, contém de herança patrimonialista da gestáo pública brasileira ou mesmo de atitudes discricionárias tomadas no interesse de nada mudar.

\section{ANÁLISE DOS RELATÓRIOS DE GRACILIANO}

$\mathrm{Na}$ leitura de ambos os relatórios priorizamos as informações quantitativas em seus demonstrativos de receita e despesa, assim como as justificativas apresentadas pelo prefeito em suas ações.

O relatório do exercício de 1928 contabiliza receita de $71.649 \$ 290$, a qual, somada ao saldo do exercício anterior, chega a $71.755 \$ 148$. Deduzida a despesa de $60.710 \$ 201$, tem-se um saldo de $11.044 \$ 947$ (valores em Réis, moeda na época de Graciliano e em vigor até 1942). Apresentado na primeira pessoa, o relatório quase nada informa sobre a origem de receitas; havendo destaque para a revisão do Código de Posturas, das maiores despesas, dos investimentos realizados e de alguns cortes de gastos mais relevantes. Além disso, o prefeito relata dificuldades com a cobrança de impostos, ações que levaram à imposição de multas, e medidas que resultaram na obtenção de juros e economia para os cofres públicos. Anuncia a demissão do tesoureiro e passa a utilizar serviços bancários em sua substituição. Os impactos financeiros na receita anunciados com eloquência pelo prefeito chegam a meros $1,8 \%$ advindos de multas e $0,9 \%$ de juros. Atualmente, tais fontes de renda seriam tipificadas como "outras receitas correntes", juntamente com restituiçôes e indenizações. Em ambos os casos, tais participaçôes no cálculo total das receitas são muito reduzidas. Encontramos aqui, então, uma coerência em termos contábeis e um zelo com o interesse público; porém com baixo impacto financeiro e muito similar àquilo que hoje se tem.

Quanto à utilização da capacidade reguladora da municipalidade sobre atividades comerciais, açôes foram adotadas para uniformizar unidades de medidas e instrumentos utilizados com distorçôes pelo comércio local para obter vantagens indevidas. Relata também açóes de limpeza de ruas e queima de lixo acumulado em fundos de quintais, matança de cães abandonados e restriçôes na permanência deles nas praças. A insistência com que essas açôes são relatadas sugerem uma prioridade ainda atual; entretanto, não escondem o personalismo do prefeito, certamente possível para o tamanho de Palmeira dos Índios da época, mas de difícil adequaçáo a cidades, ainda que de pequeno porte, de nossos tempos atuais.

Da mesma maneira como ainda hoje se observa na fala de prefeitos, com destaque para os de pequenas cidades, há reclamaçôes no relatório sobre insuficiência de recursos para realização de mais obras e sobre a incompreensão dos munícipes em relação à sua gestão. O que muda, no entanto, é o desdém de Graciliano a respeito de sua popularidade, parecendo-lhe pouco se importar com o apoio político de outras lideranças e mesmo de seus eleitores para permanecer no cargo que ocupava. 
Outro indicativo de distanciamento do chefe do governo municipal do cidadão-eleitor e de seus colaboradores diretos, relaçáo reconhecidamente não aceita em nossa atualidade, é o uso do sujeito verbal na primeira pessoa ao relatar suas açóes públicas: iniciei, lutei, dispendi, gastei, adquiri, montei, chamei, cuidei, retirei, incinerei, inseri, contratei, consertei, abri, empreendi, encontrei, retirei. Tais expressóes não significam um comportamento ditatorial, mas sim um modo operacional, muito provavelmente, no intuito de "ver as coisas acontecerem". Feita essa ressalva, e mesmo considerando-se as especificidades de uma época e de uma cidade, pode-se acreditar que há fortes sinais de que Graciliano mais conduziu os negócios da prefeitura em funçáo do que considerava, pessoalmente, como justo e correto e com vistas a dar satisfaçôes ao governador, do que com a preocupação de tornar sua gestão transparente e responsiva frente aos munícipes. De fato, nesse relatório de 1928, assim como no que segue, Graciliano Ramos procura sempre reiterar a honestidade que caracterizaria sua gestão; postura que certamente não o torna único em meio aos seus congêneres responsáveis pela gestão de prefeituras à sua época.

O segundo relatório é similar, mas acrescenta o efeito positivo na imprensa gerado pelo anterior. Deixa mais claro, porém, uma forte eloquência em defesa dos desfavorecidos. Explicita que as açôes da prefeitura se concretizavam com aplicação de dinheiro do povo e pelo esforço de assalariados "miseráveis", aproximando seu modelo de cidade idealizada daquele expresso em documentos balizadores da boa gestáo urbana da nossa atualidade. Mudam-se a forma de expressão, as palavras e a prática de gerir; restando, porém, uma essência em nível de princípios.

Diferentemente da prática relatorial atual, cuja validade repousa apenas sobre peças contábeis, Graciliano prioriza a escrita literária. Apresenta números e afirma que estão corretos. Reclamaçôes da população sobre gastos no cemitério são respondidas vagamente: "no cemitério, enterrei $189 \$ 000$ - pagamento ao coveiro e conservação [...] aos vivos ao invés de aos mortos" (PMPI, 1930, p. 21). Situaçôes como essa garantem a singularidade dos relatórios, fascinantes na leitura, mas incipientes para uma administração urbana contemporânea.

O segundo relatório não mantém a mesma estrutura contábil que permita comparaçôes diretas com seu precedente. Com breves relatos de "irregularidades muito sérias" - tal qual políticos atuais ao justificarem resultados aquém do esperado devido a "heranças malditas" de gestôes anteriores -, Graciliano afirma que a receita cresceu significativamente depois da realização de ajustes iniciais. Diferente do relatório anterior, além do detalhamento das despesas, detalha a origem de receitas municipais e a estrutura remuneratória do quadro de pessoal vinculado à prefeitura, incluindo a do próprio prefeito. Sobre a remuneração dos funcionários, o prefeito afirma que todos eram mal remunerados. Apesar de inexistir referenciais sobre o que seria uma remuneração razoável, a diferenciação remuneratória, que varia entre 5\% e 63\% do salário do prefeito sugere dúvidas sobre tal assertiva. $\mathrm{Na}$ análise das remuneraçóes por cargo na função municipal, é possível que efetivamente baixos eram os soldos de professores $(5 \%)$ - similar ao do coveiro (4\%) - e da maioria dos cargos vinculados aos serviços de justiça e polícia: situações criticadas ainda hoje.

Por último, o segundo relatório defende seus "métodos administrativos originais", contrapondo-os a políticas tradicionais que desoneravam os mais poderosos em detrimento dos mais fracos e impunham restrições remuneratórias a funcionários públicos. Distanciando-se de uma prestação de contas com base contábil, Graciliano 
enfatiza seus esforços para aliviar encargos do governador - seu aliado - e da Federação, esforçando-se, diferentemente de outros prefeitos, por realizar obras com recursos municipais.

\section{CONSIDERAÇÕES FINAIS}

De modo geral, há, no conteúdo dos dois relatórios administrativos do prefeito Graciliano, uma qualidade textual que instiga a leitura e os distingue de peças administrativas similares de sua época e da atualidade. Como documentos de prestação de conta, sob a ótica da administração contemporânea, restam dúvidas de forma (sem o necessário tecnicismo contábil contemporâneo), de conteúdo (talvez pela própria falta de modelo à época em que foram escritos), de posicionamentos (sugerindo uma ação gerencial com práticas que hoje dificilmente seriam aceitas). Tal cenário permite discutir, enfim, a experiência municipal de Graciliano Ramos como modelo de gestão a ser seguido nos dias atuais. Homem de seu tempo, deveria ser avaliado como tal. Todavia, a sua constante referência para a gestáo municipal contemporânea instiga a críticas, ainda que extemporâneas. De imediato, podemos dizer que talvez o prefeito estivesse de todo errado, mas sim, estariam frágeis os modelos que atualmente se querem construir a partir de sua administração: aqueles criados pelo senso comum e por grupos hegemônicos para aos quais mudanças estruturais não interessam.

Analisadas em um contexto maior, pode-se dizer que há, sim, nos relatórios de Graciliano especificidades positivas, pelo menos no nível das intençôes. Aquilo que aqui se questionou foi a intenção de parametrar a administração contemporânea a partir de documentos que sugerem personalismo e fragilidade documental (atributo mínimo para aquilo que buscam responder). Impossível não observar, por exemplo, o desejo em se incrementar a produçáo para elevar a arrecadação e de implementar obras urbanas e organizar a administração. Entretanto, em mais de um momento há situaçôes que permitem a crítica. A "campanha” que antecede a gestão de Graciliano, fato de ocorrência alheia ao desígnio do futuro prefeito, indica um contexto de pouco debate público, reduzida oposição e, portanto, indução natural ao personalismo: "Ninguém apareceu e ele venceu o pleito [...] com 433 votos, [...] não participou da campanha eleitoral, não fez promessas nem se envolveu em composiçóes políticas [...]" (MORAES, 2012, p. 61).

Se a falta de debate caracterizou o período pré-eleição, a curta gestão, a despeito de caracterizada por ímpetos de açôes diversas nos relatórios, pode ser vista como apática pelas palavras do próprio Graciliano em documentos não oficiais. Por mais de uma vez ele demonstrou apatia ao cargo e pouca vontade de permanecer como prefeito, fato que seria hoje tomado como desinteresse pela função e de um político pouco proativo e incapaz de impor seu intento. Esse desinteresse pessoal pela coisa política pode também ser observado em sua correspondência com a esposa Heloísa: "[...] para os cargos de administração municipal escolhem de preferência os imbecis e os gatunos, eu, que não sou gatuno, que tenho na cabeça uns parafusos de menos, mas não sou imbecil, não dou para o ofício e qualquer dia renuncio" (palavras de Graciliano Ramos apud MORAES, 2012, p. 65), ou então em "[...] isto aqui está um horror [...]. A gente emburra com rapidez extraordinária” (palavras de Graciliano Ramos apud MORAES, 2012, p. 90).

Visto desse modo, Graciliano pode parecer um gestor imobilizado por apatia e desinteresse. Porém, momentos em que se afasta da atividade mais gerencial e apro- 
xima-se da execução das coisas indicam o contrário, confirmando a figura de um homem dividido entre o agir e o tudo abandonar. Quando responsável por aquilo que hoje seria a Secretaria de Estado da Educação do Alagoas, em visita a escolas pobres, observa que alunos não podiam comprar sapatos e uniformes, o que, pela lei, os proibia de assistirem às aulas: pessoalmente, compra tecidos, vai às sapatarias, encomenda os serviços, promete pagar quando puder, volta às escolas, entrega os embrulhos e as aulas são retomadas. Esta é uma ousadia gerencial invejável - hoje não permitida -, tomada acriticamente como referência, mas não como elemento de debate relativo a legislações em vigor pensadas justamente para se garantir essa mesma agilidade.

Ao se adotar, pois, um dos principais cânones da gestão pública contemporânea, que é o diálogo negociável com os diversos grupos da sociedade como variável de análise, a gestão de Graciliano parece-nos imprópria para se constituir em exemplo, seja por razões de perfil do administrador, seja pelo contexto histórico em que se situou. Graciliano parece, de fato, pouco afeito ao debate político, lançando-se em decisóes polêmicas, a despeito de necessárias, sem conseguir articular os diversos agentes do município sobretudo aqueles com poder para lhe fazer oposição: "Os devedores são cabeçudos. [...] aqui os contribuintes pagam ao município se querem, quando querem [...] outros se julgam com autoridade bastante para dizer aos contribuintes que não paguem impostos" (RAMOS, 1930, p. 65).

$\mathrm{Na}$ eventualidade de Graciliano ter permanecido por mais tempo como prefeito, expondo, por exemplo, estratégias de reeleição, distinções administrativas entre o começo e o fim de um mandato, teríamos mais confirmaçóes sobre o que se quer concluir aqui. A maior disponibilidade de informaçóes ou o desenvolvimento de pesquisas primárias junto a arquivos públicos com esse intuito ajudaria a aprofundar o que iniciamos aqui. A exigibilidade legal de relatórios como os de Graciliano era prática que vinha do período monárquico, por meio de Circular Imperial, de 1848 (MIKI, 2014). Todavia, tais relatórios de governo "foram colecionados e incorporados a diversas instituiçóes como documentos bibliográficos, sem receber tratamento coerente com os princípios arquivísticos" (ALDABALDE, 2010, p. 16). Tais autores referemse sobretudo aos relatórios dos governos provinciais (a seguir estaduais). Para o caso dos municípios, o cuidado com a fonte e mesmo com o atendimento a uma exigência legal é ainda mais prejudicial à pesquisa. Estaria aí, entâo, a principal explicação para a dificuldade de se encontrar material similar ao de Graciliano para que pudéssemos fazer comparaçóes com seus pares prefeitos que lhe foram contemporâneos. Dentre os poucos relatórios municipais brasileiros da década de 1920 e 1930 que se teve acesso online - casos isolados e sem constituir séries históricas - o formato adotado é o protocolar: curta introdução em forma de apresentação ou ofício assinada pelo prefeito, seguida de quadros contábeis assinados pelo contador da prefeitura.

A tomada de medidas realmente transformadoras, reconhecemos, não ocorre sem crítica. Porém, mais uma vez concluindo pela valorização pouco proveitosa do modelo de gestáo de Graciliano em nossa atualidade, lembramos que uma administração política exige, também, o domínio de estratégias de coligação que possam garantir sustentação e permanência no governo. Conforme demonstra a citação a seguir, a gestão de Graciliano, a despeito de curta, logo recebe fortes críticas, incluindo mesmo ameaças à própria pessoa do prefeito: "Em uma cidade de hábitos arraigados, essas açôes moralizadoras despertaram logo inimizades e incompreensóes [...]" (palavras de Graciliano Ramos apud MORAES, 2012, p. 167). 
Se faltou estratégia em termos de coligação política, Graciliano Ramos demonstrou habilidade em atuar no nível do imediato e no do longo prazo, tal qual desejado também por administraçôes atuais. Graciliano trabalha, a um tempo, questôes de ordem mais estruturais e, portanto, com resultados mais lentos a serem observados, e também questôes mais emergenciais, de fácil constatação pela população. De um lado, conseguiu aprovar junto ao Conselho Municipal o Código de Posturas (um "calhamaço" - segundo Moraes (2012) - de 82 artigos), ou seja, significativamente complexo para um município do volume demográfico reduzido e com baixa dinâmica urbana como o de Palmeira dos Índios à sua época. De outro, avançou na busca de soluçốes emergenciais para uma populaçáo empobrecida, de falta de infraestruturas, de serviços de saúde e de escolas.

Entretanto, o elogio que se pode fazer a Graciliano por desejar atuar com uma visão de longo prazo, o que seria visto hoje como uma "visão de planejamento", logo se fragiliza. O esforço em preparar, de próprio punho, o novo Código de Posturas de Palmeira dos Índios, por exemplo, corresponde ao seu modo, não poucas vezes casuístico, de agir. Repleto de circunstâncias curiosas, seu cotidiano aproxima-se de uma informalidade, talvez infelizmente, hoje não permitida pelo extenso corpo legal que rege a gestáo urbana da atualidade: "Mas seu modo de administrar era informal. Saía cedo para vistoriar obras, andava pelo comércio com o Código de Posturas na cabeça e não hesitava em aplicar multas de próprio punho" (MORAES, 2012, p. 68).

A visão para além do cotidiano demonstrada por Graciliano fragiliza-se mais uma vez com a sua recorrente afirmativa de jamais fazer promessas aos seus munícipes: "Mas para que semear promessas que não sei se darão frutos?" (PMPI, 1929, p. 45). A despeito de seu compromisso com a verdade e com o desejo de náo decepcionar, talvez mais a si próprio que ao seu eleitorado, a opção de não fazer promessas pode, ao revés e ao olhar do planejador contemporâneo, confirmar a inexistência de plano de governo, de explicitação de coisas a fazer e de como fazê-las.

A quase totalidade do material analisado e que faz referência a Graciliano como modelo de gestão pública é condescendente a expressōes que hoje jamais seriam adotadas. Isso pode ser explicado também como deferência ao acordado valor literário do prefeito, o que dificulta a crítica, ou como permissáo de um discurso aceito para sua época. Todavia, em nenhum dos casos, vale a transferência, rápida, de seu modelo para o que hoje está idealizado. Alguns exemplos explicam essa ideia: na discussão com pedintes que não tinham pernas, Graciliano sugere a eles que usem as mãos para trabalhar; na falta de recursos para pagar a mão de obra na construçáo da estrada para Palmeira de Fora, o prefeito envia presidiários, "tirando-os da ociosidade"; na crítica aos negociantes, acusa-os de adotarem “juros de judeus" (MORAES, 2012, p. 68). Do mesmo modo, dizia: "Eu prendia os vagabundos, obrigava-os a trabalhar. E consegui fazer um pedaço de estrada e um terraplenagem difícil, contaria ele [Graciliano Ramos] em 1948 (palavras de Graciliano Ramos apud MORAES, 2012, p. 69).

A pretensão do poder de decisão final está presente em momentos diversos da gestão de Graciliano. São momentos folclorizados, mas de difícil consecução, pelo certo ou pelo errado, nos tempos atuais. Num atualmente impensável modo de fazer valer o interesse da utilidade pública de alguma intervençáo, Graciliano náo hesita, por exemplo, em enfrentar pessoalmente o proprietário de área rural sobre a qual passaria seu projeto de estrada. 
A firmeza de Graciliano foi colocada à prova durante a construção da estrada para Palmeira de Fora. Os operários esbarraram na disposição de um fazendeiro de não permitir obras em suas terras. O prefeito compareceu ao local e mandou cortar as roças de milho. De nada valeram os protestos do latifundiário. Seu milho ia dar aqui a noventa dias, mas o senhor já o colheu agora. Vá à prefeitura receber seu dinheiro (MORAES, 2012, p. 67).

Por último, uma questão que ainda requer mais análises pela grande distância que separa o tempo de Graciliano das atuais preocupaçóes com o meio ambiente urbano. Ao mesmo tempo que Graciliano mostrava-se obstinado com a necessária revisão de hábitos urbanos, determinando a limpeza de ruas e logradouros públicos, onde proliferavam animais vadios, lixo acumulado lama e detritos, houve também um questionável aterramento de área no bairro da Lagoa (MORAES, 2012). Temos aqui uma prática de difícil julgamento, contextualizada que estava em uma época onde o conceito de desenvolvimento era restrito e preocupaçóes ambientais ainda distantes de serem valorizadas. Não há, porém, a ação visionária. Se não podemos julgá-lo, também não podemos elogiá-lo, no limite da questão analisada, como um gestor para além de seu tempo vivido. Para o retrato de um prefeito visionário, parece-nos mais correto limitarmos ao seu esforço de accountability, hoje difundido. Aliás, essa foi a função precípua dos relatórios. Ainda assim, Cruz et al. (2010, p. 94), ao reiterar a lisura, chamam a atenção para o não atendimento aos preceitos contábeis já estabelecidos na década de 1920: "Graciliano Ramos se preocupava em atender o que era previsto no orçamento, e sem ser um visionário já praticava a accountability [...]. Porém, pelos relatórios encontrados não se pode evidenciar como era realizada a contabilidade em suas partidas dobradas prevista pelo Decreto no 4.536 de 28 de janeiro de 1922".

A transferência pouco cuidadosa de ideias de um momento histórico para outro, como visto para o caso de Graciliano, apoia-se numa síntese frágil do passado e numa pouco consistente proposição para a atualidade urbana. A despeito da justificada valorização atual dos princípios com que Graciliano regeu a coisa pública, tal situação sugere uma transferência do respeito que dele tradicionalmente tem como escritor para uma avaliação idílica, pouco fundamentada, dele como prefeito.

\section{REFERÊNCIAS}

ALDABALDE, T. V. A presença do arquivo nos relatórios dos presidentes de província no Brasil (1835-1889). 2010. Dissertação (Mestrado em História Social) - Faculdade de Filosofia, Letras e Ciências Humanas, Universidade de São Paulo, São Paulo, 2010.

AYUB, J. P. O estatuto da linguagem no romance Caetés. Acta Scientiarum. Language and Culture, v. 38, n. 1, p. 51-60, jan./mar. 2016. https://doi.org/10.4025/actascilangcult. v38i1.25826

BRASIL. Ministério da Agricultura, Industria e Commercio. Directoria Geral de Estatística. Recenseamento do Brasil de 1920. Rio de Janeiro: Typ. da Estatística, 1926.

CÂNDIDO, A. Fiç̧âo e confissão: ensaios sobre Graciliano Ramos. Rio de Janeiro: Editora 34, 1992.

CARVAlHO, J. M. Mandonismo, Coronelismo, Clientelismo: uma Discussão Conceitual. Dados, v. 40, n. 2, 1997. https://doi.org/10.1590/s0011-52581997000200003

CORRÊA, R. L. A Vida Urbana em Alagoas: a importância dos meios de transporte na sua evolução. Terra Livre, n. 10, p. 93-116, jan./jul. 1992. Disponível em: <http://www.agb.
Clovis Ultramari é graduado em Arquitetura e Urbanismo e doutor em Meio Ambiente e Desenvolvimento pela Universidade Federal do Paraná (UFPR); professor no Programa de Pós-Graduação em Gestão Urbana da Pontifícia Universidade Católica do Paraná (PPGTU/PUC-PR); bolsista de produtividade do CNPq

E-mail: ultramari@yahoo. com

Mario Procopiuck é graduado em Administração pela Universidade Federal do Paraná (UFPR); mestre e doutor em Gestão Urbana pela Pontifícia Universidade Católica do Paraná (PUC-PR) professor no Programa de Pós-Graduação em Gestão Urbana (PPGTU) da PUC-PR.

E-mail: mario.p@pucpr.br

Manoela Massuchetto Jazar é graduada em Arquitetura e Urbanismo, mestra e doutoranda em Gestão Urbana pela Pontifícia Universidade Católica do Paraná (PUC-PR).

E-mail: manoelamj.arq@ gmail.com

Artigo recebido em 10 de novembro de 2015 e aprovado para publicação em 27 de maio de 2016. 
org.br/publicacoes/index.php/terralivre/article/view/115>. Acesso em: 15 dez. 2016.

CRUZ, V. L. et al. Uma análise das práticas de evidenciação contábil sob a ótica de Graciliano Ramos nos anos de 1928 e 1929. Revista de Contabilidade e Controladoria, v. 2, n. 6, p. 81-95, mai./ago. 2010. Disponível em: <http://revistas.ufpr.br/rcc/article/ view/20113/13335>. Acesso em: 15 dez. 2016.

DIEGUES JR. M. De um relatório a um romance. Jornal O Estado, Recife, 27 fev. 1934. In: LIMA, M. H. G. (Org.). Relatórios. Rio de Janeiro: Record, 1994.

FELDMAN, S. Avanços e limites na historiografia da Legislação Urbanística no Brasil. Revista Brasileira de Estudos Urbanos e Regionais, n. 4, p. 33-48, maio 2001. http:// dx.doi.org/10.22296/2317-1529.2001n4p33

Entre o Regional e o Metropolitano: Pensamento Urbanístico e Metrópole no Brasil na Década de 1950. Revista USP, n. 102, p. 13-22, jun./ago. 2014. https://doi. org/10.11606/issn.2316-9036.v0i102p13-22

FOUCAULT, M. A arqueologia do saber. 7. ed. Rio de Janeiro: Forense Universitária, 2008.

GIMENEZ, E. T. Caetés: nossa gente é sem herói. Revista do Instituto de Estudos Brasileiros, n. 47, p. 161-181, set. 2008. https://doi.org/10.11606/issn.2316-901x.v0i47p161-180

HALL, P. Cidades do amanhã. São Paulo: Perspectiva, 2011.

HEALEY, P. The universal and the contingent: Some reflections on the transnational flow of planning ideas and practices. Planning Theory, v. 11, n. 2, p.188-207, 2012. https://doi. org/10.1177/1473095211419333

; UPTON, R. Crossing Borders. International exchange and planning practices. London: Routledge, 2010.

HOWLETT, P.; MORGAN, M. S. (Ed.). How well do facts travel: the dissemination of reliable knowledge. Cambridge: Cambridge University Press, 2010.

INSTITUTO BRASILEIRO DE GEOGRAFIA E ESTATÍSTICA (IBGE). Censo Demográfico de 2010. Rio de Janeiro: IBGE, 2010.

JACONI, S. M. R. A transgressão sertaneja do gênero relatório: revelação do escritor no texto do prefeito Graciliano Ramos. 2012. Tese (Doutorado em Comunicação Social) - Universidade Metodista de São Paulo, São Paulo, 2012. Disponível em <http://ibict.metodista.br/ tedeSimplificado/tde_busca/arquivo.php?codArquivo=3233>. Acesso em: 15 dez. 2016.

JAMETT, A. V. S. Plan de Reconstrucción de 1906-1910: sus Ideas Urbanas hacia el Centenario de la República. 2009. Trabalho de Conclusão de Curso (Licenciatura em História) Escuela de Historia, Universidad Academia de Humanismo Cristiano, Santiago, 2009. Disponível em: <http://bibliotecadigital.academia.cl/bitstream/handle/123456789/71/ this03.pdf?sequence=1>. Acesso em: 15 dez. 2016.

JORNAL O SEMEADOR. A prefeitura de Palmeira. Alagoas, 4 de fevereiro de 1929. In: LIMA, M. H. G. (Org.). Relatórios. Rio de Janeiro: Record, 1994.

JORNAL CORREIO DA PEDRA. Prefeitos Laboriosos. Alagoas, 15 de setembro de 1929. In: LIMA, M. H. G. (Org.). Relatórios. Rio de Janeiro: Record, 1994.

LEAL, V. N. Coronelismo, enxada e voto: o município e o regime representativo no Brasil. Rio de Janeiro: Nova Fronteira, 1997.

LEME, M. C. S. A formação do pensamento urbanístico no Brasil: 1895-1965. In: (Org.). Urbanismo no Brasil 1895-1965. São Paulo: Studio Nobel; FAU/USP; FUPAM, 1999. p. 20-39.

. A circulação de idéias e modelos na formação do urbanismo em São Paulo, nas primeiras décadas do século XX. In: SEMINÁRIO DE HISTÓRIA DA CIDADE E DO URBANISMO, 8., 2004, Niterói. Anais... Niterói: PPFAU/UFF, 2004. Disponível em <http://unuhospedagem.com.br/revista/rbeur/index.php/shcu/article/view/946> Acesso em: 15 dez. 2016.

LUZ, N. V. A Década de 1920 e suas crises. Revista do Instituto de Estudos Brasileiros, n. 6, p. 
67-75, jul. 1969. https://doi.org/10.11606/issn.2316-901x.v0i6p67-75

MAIA, A. S. A Importância do Tribunal de Contas da União. Revista do TCU, n. 98, p. 25-28, out. dez. 2003. Disponível em: <http://revista.tcu.gov.br/ojsp/index.php/ RTCU/article/view/691>. Acesso em: 15 dez. 2016.

MEIRELLES, H. L. Direito Municipal Brasileiro. São Paulo: Malheiros, 1996.

MELLO, M. S. Breve história da consagração literária de Graciliano Ramos: a recepção de Vidas Secas. Revista Lingua \& Literatura, v. 14, n. 22, p. 1-250, ago. 2012. Disponível em: <http://revistas.fw.uri.br/index.php/revistalinguaeliteratura/article/viewFile/319/732>. Acesso em: 15 dez. 2016.

MIKI, P. S. B. Aspectos Da Educação Infantil No Estado do Amazonas: o curso infantil Froebel no Instituto Benjamin Constant e outros Jardins de Infância (1897-1933). 2014. Tese (Doutorado em Educação) - Universidade São Francisco, Itatiba, 2014. Disponível em: <https:// www.usf.edu.br/galeria/getImage/427/14501785604281727.pdf>. Acesso em: 15 dez. 2016.

MONTORO, E. F. O Município na constituição brasileira. São Paulo: Jurid Vellenich, 1975.

MORAES, D. O velho Graça: uma biografia de Graciliano Ramos. São Paulo: Boitempo, 2012.

MÜLLER, M. (Im-)Mobile policies: Why sustainability went wrong in the 2014 Olympics in Sochi. European Urban and Regional Studies, v. 22, n. 2, p. 191-209, 2015. https://doi. org/10.1177/0969776414523801

ORTEGA Y GASSET. Meditaciones del Quijote. Madrid: Publicaciones y la Residencia de Estudiantes, 1914.

PAES, A. C. Mensagem ao Congresso legislativo. Imprensa Oficial: Maceió, 1929. In: LIMA, M. H. G. (Org.). Relatórios. Rio de Janeiro: Record, 1994.

PARNREITER, C. Towards the Making of a Transnational Urban Policy? Journal of Planning Education and Research, v. 31, n. 4, p. 416-422, 2011.

PREFEITURA MUNICIPAL DE PALMEIRA DOS ÍNDIOS (PMPI). Relatório ao governador do estado de alagoas, por Graciliano Ramos, 1929. In: LESSA, F. L. Relatórios de Graciliano Ramos: uma obra-prima da literatura e uma contribuição inestimável à gestáo pública, Cultura e Viagem, 8 mar. 2013. Disponível em: <http://culturaeviagem. wordpress.com/2013/03/08/relatorios-de-graciliano-ramos-uma-obra-prima-da-literatura-e-uma-contribuicao-inestimavel-a-gestao-publica>. Acesso em: 15 dez. 2016.

. 20 Relatório ao Sr. governador Álvaro Paes, pelo prefeito do município de Palmeira dos Índios, Graciliano Ramos, 1930. In: O Globo, 13 fev. 2013. Disponível em: <http:// oglobo.globo.com/pais/noblat/posts/2013/02/13/graciliano-ramos-da-prefeituramunicipal-de-palmeira-dos-indios-1930-486134.asp>. Acesso em: 01 mar. 2014.

Dados do site oficial da prefeitura de Palmeira dos Índios, 2014. Disponível em: <http://www.palmeiradosindios.al.gov.br/>. Acesso em: 08 mar. 2014.

RAMOS, E. Relatórios de Graciliano Ramos publicados no Diário Oficial. Maceió: Editora do Diário Oficial, 2013.

RAMOS, G. Cartas. 6. ed. Rio de Janeiro: Record. 1986. Caetés. Rio de Janeiro: Record, 2013.

REGO, J. L. O romancista Graciliano Ramos. Boletim de Ariel. Rio de Janeiro, s/d (circa 1934). ROJAS MUÑOZ, J. La ciudady la representación visual. Valparaíso: Univ. de Valparaíso, 1989.

ROUANET, S. As minas iluminadas. In: NOVAIS, A. (Org.). Tempo e História. São Paulo: Cia. das Letras, 1992. p. 329-345.

SALLA, T. M. O fio da navalha: Graciliano Ramos e a revista cultura política. 2010. 720 f. Tese (Doutorado em Ciências da Comunicação) - Escola de Artes e Comunicação, Universidade de São Paulo, São Paulo, 2010.

SANT'ANA, M, M. História do Modernismo em Alagoas: 1922-1932. Maceió: UFAL, 2003.

SANTOS, S. Tendências da urbanização brasileira no fim de século XX. In: CARLOS, A. F. 
A. (Org.). Os Caminhos da Reflexão sobre a Cidade e o Urbano. São Paulo: Edusp, 1994. p. 19-30.

. A natureza do espaço: técnica e tempo, razão e emoção. São Paulo: Hucitec, 1996.

SANTOS, R. A. A Lei de Responsabilidade Fiscal e o desenvolvimento do capital social. Revista Controle, v. 7, n. 1, p. 31-40, abr. 2009. Disponível em: <https://www.usf.edu. br/galeria/getImage/427/14501785604281727.pdf>. Acesso em: 15 dez. 2016.

SCHWARZ, R. Ao vencedor as batatas: forma literária e processo social nos inícios do romance brasileiro. São Paulo: Duas Cidades, 1981.

SILVEIRA, P. C. Graciliano Ramos, nascimento, vida, glória e morte. Maceió: Fundação Deodoro, 1982. Disponível em: <http://www.oocities.org/gracilianoramos/pol. htm\#PREFEITO>. Acesso em: 15 dez. 2016.

STONE D. Transfer agents and global networks in the "transnationalisation" of policies. Journal of European Public Policy, v. 11, n. 3, p. 545-566, 2004. http://dx.doi.org/10.10 80/13501760410001694291

TAVARES, Z. As lições do prefeito Graciliano Ramos. Ciências Contábeis, 11 abr. 2011. Disponível em: <http://clickcontabeis.blogspot.com.br/2011/04/as-licoes-do-prefeitograciliano-ramos.html>. Acesso em: 15 dez. 2016.

TOMLINSON, R. et al. The Influence of Google on Urban Policy in Developing Countries. International Journal of Urban and Regional Research, v. 34, n. 1, p. 174-189, mar. 2010. https://doi.org/10.1111/j.1468-2427.2010.00933.x

TRIBUNAL DE CONTAS DA UNIÃO (TCU). Ata no 8, de 25 de março de 2003, Sessão Ordinária. Disponível em: <http://portal2.tcu.gov.br/portal/pls/portal/docs/2047134. PDF>. Acesso em: 15 dez. 2016.

Pronunciamento do Sr. Marco Maciel sobre posse de presidente do TCU, Sr. Guilherme Palmeira, 2006. Disponível em: <https://www25.senado.leg.br/web/atividade/pronunciamentos/-/p/texto/364233> Acesso em: 15 dez. 2016.

Ministros do Tribunal de Contas da União: dados biográficos. Brasília: TCU, 2008. Disponível em <http://portal2.tcu.gov.br/portal/pls/portal/docs/2058944.PDF>. Acesso em: 15 dez. 2016.

Ato TC 011.188/2007-0, ano 2012. Disponível em: <www.tcu.gov.br/Consultas/ Juris/.../20121112/AC_2657_39_12_P.doc >. Acesso em: 15 dez. 2016.

ULTRAMARI, C.; FIRKOWSKI, O. L. Sobre mudanças e continuidades na gestão urbana brasileira. Mercator, v. 11, n. 24, p. 73-88, jan./abr. 2012. https://doi.org/10.4215/ rm2012.1124.0005

; DUARTE, F. Inflexóes Urbanas. Curitiba: Champagnat, 2009.

VIEGAS, T. Administraçáo da linguagem: texto da prova do concurso para agente de defensoria. São Paulo: DP/SP, 2010. Disponível em: <http://www.tecnolegis.com/provas/ $\mathrm{id} / 1307$ - defensoria-publica-do-estado-sao-paulo-agente-de-defensoria-psicologo-fcc2010-prova- objetiva>. Acesso em: 15 dez. 2016. 